\title{
Analysis of the performance management within industrial systems: a case study
}

\author{
Flavia Fechete*, and Anişor Nedelcu \\ ${ }^{1}$ Transilvania University of Brașov, Department of Manufacturing Engineering, Mihai Viteazu No.5, \\ Braşov, Romania.
}

\begin{abstract}
Improving performance has become one of the critical issues for gaining competitive advantages for companies. Monitoring and improvement of the industrial systems' performance has become an increasingly complex task. In order to improve performance, companies have to implement a performance management system. This paper aims to analyze the performance management system within a multinational company. There will be analyzed the performance indicators monitored by the company and the models used to evaluate the performance. The aim of the study is to identify potential causes that led to getting poor performance; that will allow highlighting areas where goals were not achieved in order to apply the proper measures for improvement.
\end{abstract}

\section{Introduction}

Industrial system's performance is the relative size by which it can be characterized the activity of the production systems, using specific indicators [1].

Improving the strategic performance, the operational, team or the individual performance is a major objective of any company.

Performance management is the mode in which the entity ensures a sustainable success in their activity by improving the performance of the organization, of the team or the individual performance $[2,3]$.

Performance is measured and evaluated using criteria or performance indicators. In order to obtain a true and fair view of the performance, entities must implement a system of indicators. Indicators are used for proper evaluate, report and improve the organizational performance $[4,5]$.

This paper aims to examine the manner that performance management is achieved in an industrial system. Thus, there will be analyzed the key performance indicators monitored by the company in order to propose improving measures for the identified risk areas. Performance improvement is proposed to be achieved by identifying and analyzing root causes using 5 Whys technique. Root cause analysis is a method used by the performance management within developed companies. The method is considered a primary-method to be used in the early stages of specific analysis of the process management [6].

\footnotetext{
*Corresponding author: fechete_flavia@yahoo.com.
} 


\section{Industrial system's performance management. A case study}

The experimental research was conducted in the Automotive division of a multinational company and it was concentrated on the product "outer ring" for roller cam followers.

Processing technology for pieces like "outer ring" involves achieving the following main steps: turning, surface grinding, centerless grinding, outer diameter grinding by vibrating, interior grinding and super finishing.

Performance management in the segment $\mathrm{Z}$ of the multinational company which manufactures parts like "outer ring" is achieved by daily monitoring of a set of nine key performance indicators and by taking immediate measures to improve where it is necessary (where the goal was not reached or which exceeded the goal set in a negative manner).

The key performance indicators that are monitored and evaluated in the multinational company are shown in Table 1.

Table 1. Key performance indicators tracked by the multinational company.

\begin{tabular}{|c|c|c|c|c|}
\hline Indicator & Definition & $\begin{array}{c}\text { Measurement } \\
\text { units }\end{array}$ & $\begin{array}{c}\text { Frequency } \\
\text { of } \\
\text { calculation } \\
\end{array}$ & Response \\
\hline $\begin{array}{l}\text { Non quality } \\
\text { costs }\end{array}$ & $\begin{array}{l}\text { Expenses incurred if } \\
\text { the product does not } \\
\text { meet quality } \\
\text { requirements. }\end{array}$ & Percentage & Daily & $\begin{array}{c}\text { Taking } \\
\text { measures } \\
\text { in case of } \\
\text { exceeding } \\
\text { the goal }\end{array}$ \\
\hline Complaints & $\begin{array}{l}\text { Non-compliance of } \\
\text { the product delivered } \\
\text { to the client. }\end{array}$ & Pieces & Daily & $\begin{array}{c}\text { Taking } \\
\text { measures } \\
\text { in case of } \\
\text { complaints }\end{array}$ \\
\hline Delivery & $\begin{array}{l}\text { Cumulation of the } \\
\text { previous day } \\
\text { deliveries. }\end{array}$ & Percentage & Daily & Escalation \\
\hline Backlogs & $\begin{array}{l}\text { Cumulation of the } \\
\text { previous day } \\
\text { backlogs. }\end{array}$ & Percentage & Daily & Escalation \\
\hline Stocks & $\begin{array}{l}\text { Accumulation of the } \\
\text { quantity of goods } \\
\text { available as backup. }\end{array}$ & $\mathrm{DOH}$ & Daily & $\begin{array}{l}\text { Long-term } \\
\text { plan to } \\
\text { reduce } \\
\text { inventory }\end{array}$ \\
\hline Productivity & $\begin{array}{l}\text { The ratio between the } \\
\text { manufactured } \\
\text { products and } \\
\text { workload. }\end{array}$ & $\mathrm{EUR} / \mathrm{h}$ & Daily & $\begin{array}{c}\text { Taking } \\
\text { special } \\
\text { measures } \\
\text { and } \\
\text { immediate } \\
\text { action }\end{array}$ \\
\hline $\begin{array}{c}\text { Work } \\
\text { accidents }\end{array}$ & $\begin{array}{c}\text { Number of workplace } \\
\text { accidents. }\end{array}$ & Number & Daily & \\
\hline
\end{tabular}

Table 1 presents the main key performance indicators assessed daily by the multinational company: non quality costs, customer complaints, performed deliveries, backlogs, stocks, work productivity and work accidents; each indicator has a proper 
definition, a unit of measurement, a calculation formula and a method of action in case of not achieving the established goal.

As the quality of industrial production is a prerequisite for achieving performance [3], special attention will be given to non quality costs indicator.

Non quality costs relate to expenses incurred if the product does not meet quality requirements. It can be seen a downward trend in this indicator towards the end of the review period (Fig.1).

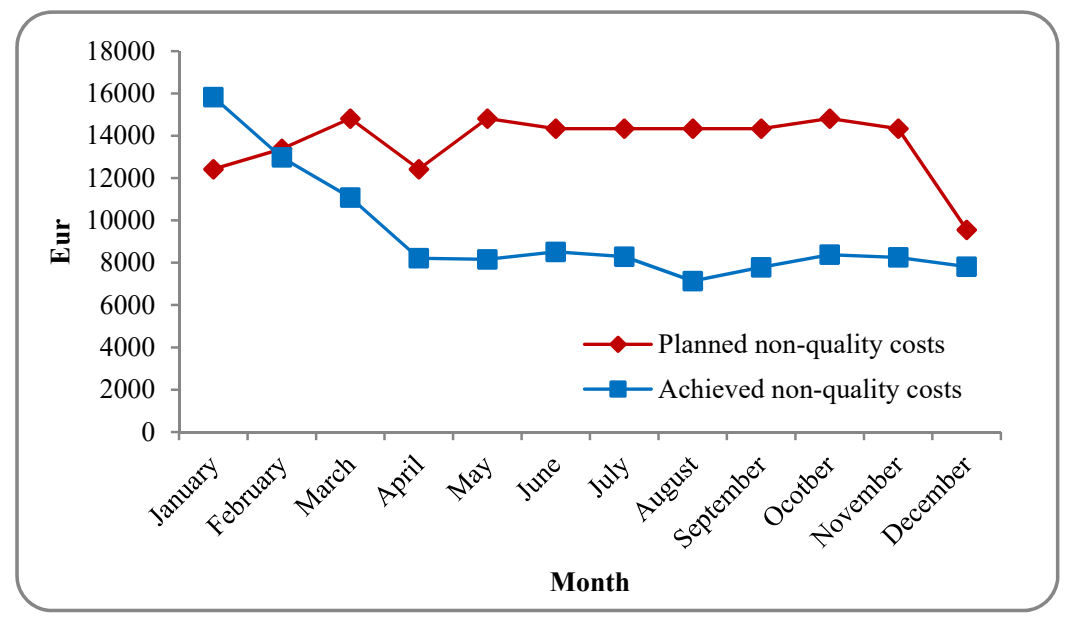

Fig.1. Evolution of non-quality costs in the period January to December 2015 for the multinational company.

In order to identify the distribution of non-quality costs, a Pareto chart was conducted (shown in Figure 3), which notes that over 50\% of the non-quality costs in 2015 are represented by scrap parts.

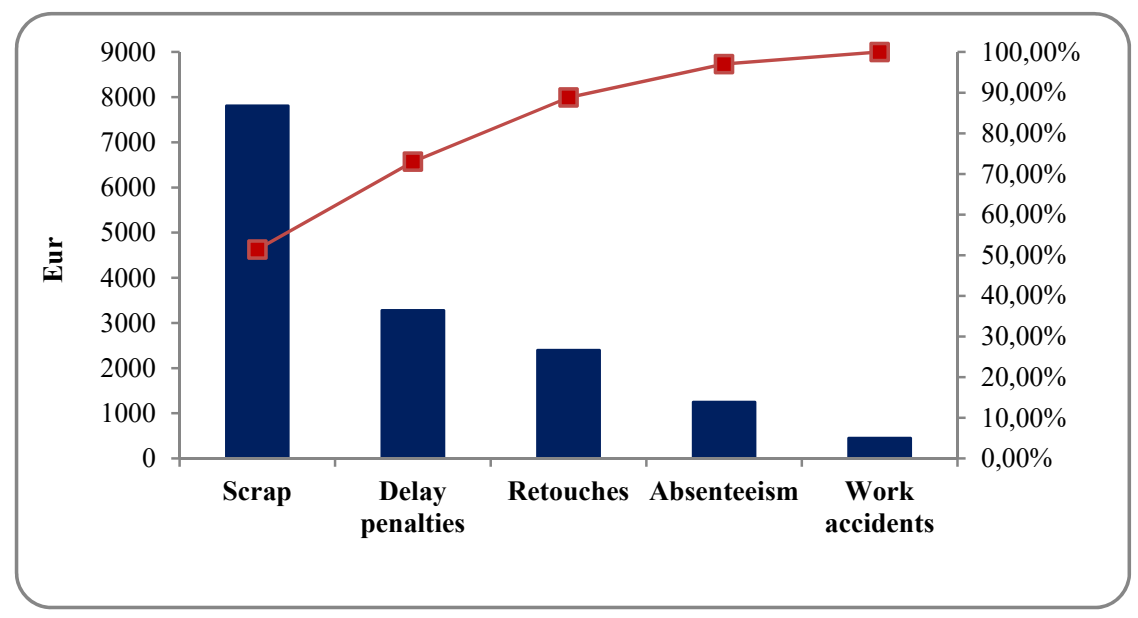

Fig.2. Pareto chart of the distribution of the non-quality costs in the multinational company. 
In order to identify the poor performance on the part of scrap in the process of bore grinding it would be used the 5 Whys technique (Table 2). Asking "why" five consecutive times is an approach that many Six Sigma practitioners use to help identify the "root cause" of a problem or a defect [7]. Using a series of questions "why?", this technique is meant to explore the cause and effect relationships or work process, highlighting a particular problem. The goal is to find the essence of the problem in order to correct it $[8,9]$.

Table 2. 5 Whys analysis applied for the bore grinding process.

\begin{tabular}{|c|c|c|c|c|c|}
\hline Category & $1^{\text {st }}$ Why & $2^{\text {nd }}$ Why & $3^{\text {rd }}$ Why & $4^{\text {th }}$ Why & $5^{\text {th }}$ Why \\
\hline \multirow{6}{*}{$\begin{array}{l}\text { Scrap parts } \\
\text { after set-up } \\
\text { of the } \\
\text { machine }\end{array}$} & \multirow{3}{*}{$\begin{array}{l}\text { The } \\
\text { machine } \\
\text { get's cold } \\
\text { (the } \\
\text { broach, } \\
\text { guides, } \\
\text { grinding } \\
\text { stone) }\end{array}$} & \multirow{3}{*}{$\begin{array}{c}\text { Long } \\
\text { down } \\
\text { times of } \\
\text { the } \\
\text { machine } \\
\text { Lack of } \\
\text { raw } \\
\text { material }\end{array}$} & $\begin{array}{l}\text { Machine } \\
\text { break down } \\
\text { that is not } \\
\text { repaired for } \\
\text { long time }\end{array}$ & $\begin{array}{l}\text { Because there is } \\
\text { only one setting } \\
\text { person on the shift }\end{array}$ & \\
\hline & & & $\begin{array}{l}\text { The planning } \\
\text { was } \\
\text { inadequate } \\
\text { and it wasn't } \\
\text { planned } \\
\text { enough raw } \\
\text { material }\end{array}$ & \multirow[t]{2}{*}{$\begin{array}{l}\text { The production is } \\
\text { not monitored }\end{array}$} & \\
\hline & & & $\begin{array}{l}\text { The planning } \\
\text { of the } \\
\text { production is } \\
\text { not respected }\end{array}$ & & \\
\hline & \multirow{3}{*}{$\begin{array}{l}\text { The tools } \\
\text { needs to } \\
\text { be } \\
\text { changed } \\
\text { often }\end{array}$} & $\begin{array}{c}\text { Re- } \\
\text { adjustment } \\
\text { of the } \\
\text { machine }\end{array}$ & & & \\
\hline & & \multirow[b]{2}{*}{$\begin{array}{l}\text { Machine } \\
\text { break } \\
\text { down }\end{array}$} & $\begin{array}{l}\text { Because of } \\
\text { ends of raw } \\
\text { material got } \\
\text { in the bore } \\
\text { grinding }\end{array}$ & $\begin{array}{l}\text { Ends of raw } \\
\text { material not } \\
\text { detected }\end{array}$ & \\
\hline & & & $\begin{array}{l}\text { Mixed up } \\
\text { parts from } \\
\text { the turning, } \\
\text { heat } \\
\text { treatment, } \\
\text { calibration }\end{array}$ & $\begin{array}{l}\text { After changing } \\
\text { the part-time at } \\
\text { turning/calibration } \\
\text { remain parts from } \\
\text { the previous } \\
\text { operation }\end{array}$ & $\begin{array}{c}\text { The } \\
\text { instruction } \\
\text { for } \\
\text { changing } \\
\text { and } \\
\text { cleaning } \\
\text { the } \\
\text { machine } \\
\text { is not } \\
\text { respected }\end{array}$ \\
\hline $\begin{array}{l}\text { Tools are not } \\
\text { changed on } \\
\text { time }\end{array}$ & $\begin{array}{c}\text { There is } \\
\text { not } \\
\text { enough } \\
\text { personnel } \\
\text { to change } \\
\text { the tools }\end{array}$ & & & & \\
\hline
\end{tabular}




\begin{tabular}{|c|c|c|c|c|c|}
\hline & on time & & & & \\
\hline \multirow{4}{*}{$\begin{array}{c}\text { Grinding } \\
\text { stone broken }\end{array}$} & $\begin{array}{l}\text { Parts with } \\
\text { degree }\end{array}$ & $\begin{array}{c}\text { Lack of } \\
\text { chamfer at } \\
\text { inner } \\
\text { diameter }\end{array}$ & $\begin{array}{l}\text { The mill is } \\
\text { broken }\end{array}$ & $\begin{array}{l}\text { Because of an } \\
\text { incorrect } \\
\text { adjustment }\end{array}$ & $\begin{array}{l}\text { There is } \\
\text { not a } \\
\text { standard } \\
\text { way to } \\
\text { adjust the } \\
\text { machine }\end{array}$ \\
\hline & $\begin{array}{l}\text { Parts with } \\
\text { variation } \\
\text { at the } \\
\text { outer } \\
\text { diameter }\end{array}$ & $\begin{array}{l}\text { Because } \\
\text { of the } \\
\text { tolerance } \\
\text { at exterior } \\
\text { grinding }\end{array}$ & & & \\
\hline & \multirow{2}{*}{$\begin{array}{l}\text { The } \\
\text { machine } \\
\text { did not } \\
\text { removed } \\
\text { chips at } \\
\text { grinding }\end{array}$} & \multirow{2}{*}{$\begin{array}{l}\text { Lack of } \\
\text { material } \\
\text { on inner } \\
\text { diameter }\end{array}$} & $\begin{array}{l}\text { Because the } \\
\text { drill could be } \\
\text { bigger at } \\
\text { turning } \\
\text { operation }\end{array}$ & $\begin{array}{l}\text { They mixed the } \\
\text { tools when they } \\
\text { took them from } \\
\text { the tool } \\
\text { preparation }\end{array}$ & \\
\hline & & & $\begin{array}{l}\text { Because of } \\
\text { the mill that } \\
\text { cuts } \\
\text { inappropriate }\end{array}$ & $\begin{array}{l}\text { Because of the } \\
\text { incorrect } \\
\text { adjustment }\end{array}$ & $\begin{array}{l}\text { There is } \\
\text { not a } \\
\text { standard } \\
\text { way to } \\
\text { adjust the } \\
\text { machine }\end{array}$ \\
\hline \multirow{2}{*}{$\begin{array}{l}\text { Parts with } \\
\text { black spots } \\
\text { or roundness } \\
\text { after bore } \\
\text { grinding }\end{array}$} & \multirow{2}{*}{$\begin{array}{l}\text { Because } \\
\text { the parts } \\
\text { from the } \\
\text { lathe have } \\
\text { run out }\end{array}$} & $\begin{array}{l}\text { Because at } \\
\text { the turning } \\
\text { they don't } \\
\text { work with } \\
\text { covered } \\
\text { tools }\end{array}$ & & & \\
\hline & & $\begin{array}{l}\text { The drill } \\
\text { from the } \\
\text { turning } \\
\text { operations } \\
\text { it is not } \\
\text { well } \\
\text { sharpened }\end{array}$ & $\begin{array}{l}\text { Sharpened } \\
\text { internally } \\
\text { with } \\
\text { different } \\
\text { method from } \\
\text { the supplier }\end{array}$ & & \\
\hline $\begin{array}{lr}\text { Too much } \\
\text { material to } \\
\text { process } \\
\text { bore } \\
\text { grinding }\end{array}$ & $\begin{array}{l}\text { Change of } \\
\text { the } \\
\text { calibration } \\
\text { process } \\
\text { with a } \\
\text { smaller } \\
\text { ball }\end{array}$ & & & & \\
\hline
\end{tabular}

5 Whys analysis allowed the identification of detailed root causes that led getting a large percentage of scrap in the process of bore grinding. Further analysis using statistical methods such as regression analysis will allow identifying the exact causes and the immediate intervention action to reduce the percentage of the scrap obtained.

Table 3 shows the six main causes that led to an increasing number of scrap, according to the high coefficient of confidence given by the team of specialists. 
Table 3. Identified main root causes for scrap parts.

\begin{tabular}{|c|c|c|}
\hline & Identified root cause & Conclusion \\
\hline 1 & $\begin{array}{l}\text { Not enough personnel at bore } \\
\text { grinding (for corrections) }\end{array}$ & $\begin{array}{l}\text { In the days with only } 3 \text { persons on the line } \\
\text { the scrap rate was higher than the days with } \\
4 \text { persons on the line. }\end{array}$ \\
\hline 2 & $\begin{array}{l}\text { The spread of exterior diameter } \\
\text { at bore grinding }\end{array}$ & $\begin{array}{c}\text { The operator does not make corrections on } \\
\text { time }\end{array}$ \\
\hline 3 & $\begin{array}{l}\text { Setting parts with different value } \\
\text { from the one on the label }\end{array}$ & $46 \%$ of the setting parts were not ok \\
\hline 4 & $\begin{array}{l}\text { Too much added material at bore } \\
\text { grinding }\end{array}$ & $\begin{array}{c}\text { When changing the calibration ball with one } \\
\text { bigger, the scrap rate was significant smaller } \\
\text { than usual }\end{array}$ \\
\hline 5 & Black spots at bore grinding & $\begin{array}{l}\text { There are many parts that have runout at } \\
\text { turning and when reaching bore grinding } \\
\text { black spots appear on the surface }\end{array}$ \\
\hline 6 & Scrap parts after dressing & $\begin{array}{l}\text { After each dressing of the machine approx. } \\
5 \text { parts are scrap. }\end{array}$ \\
\hline
\end{tabular}

\section{Conclusions}

This paper aims to analyze the manner that performance management is achieved in an industrial system. The research revealed that the industrial system uses a total of nine key performance indicators that are monitored daily, also being taken necessary measures to improve the obtained results.

As quality is the prerequisite to achieve performance, special attention was paid to the indicator of non-quality costs. Pareto analysis showed that over $50 \%$ of non-quality costs are the scrap parts.

This paper aims to identify potential causes that led to getting the high percentage of scrap, which will allow applying the appropriate improvement measures in order to increase the performance of the analyzed industrial system. The application of the 5-whys analysis provides a fact based and structured approach to problem identification and correction that focuses on not only reducing defects but also in eliminating them.

\section{References}

1. H. Aguinis, J. Harry, B.H. 55, 385 (2012).

2. M. Armstrong, Management of human resources (Codex Published House, Bucharest, 2001).

3. A. Draghici, A. Popescu, L. Gogan, P.S.B.S 124, 544 (2014).

4. F. Osmani, G. Maliqi, P.S.B.S. 41, 434 (2012).

5. J. Cai, X. Liu, D.S.S 46, 512 (2009).

6. U. Dombrowskia, T. Mielkea, P.C.I.R.P. 7, 569 (2013).

7. A. Ayad, J.M.D 29, 556 (2010).

8. E. D. Arnheiter, J. Maleyeff, T.Q.M.M 17, 5 (2005).

9. U. Murugaiah, S. J. Benjamin, M. S. Marathamuthu, S. Muthaiyah, I.J.Q.R.M 27, 527 (2010). 